\title{
Inbreeding depression level of post-larvae freshwater prawn (Macrobrachium rosenbergii) from several hatcheries in Java, Indonesia
}

\author{
ROBI BINUR ${ }^{1, \vartheta}$, ADI PANCORO ${ }^{2, \vee \varphi}$ \\ ${ }^{1}$ Laboratory of Zoology, Department of Biology, Faculty of Mathematics and Natural Sciences, Universitas Papua. Jl. Gunung Salju Amban, Manokwari \\ 98314, West Papua, Indonesia. ”email: robi.binur@yahoo.co.id \\ ${ }^{2}$ Laboratory of Genetics and Biomolecular, Department of Biotechnology, Labtex. IX, School of Life Sciences and Technology, Institut Teknologi

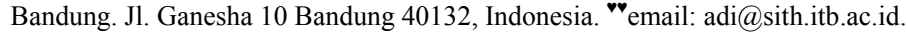

Manuscript received: 2 September 2016. Revision accepted: 21 March 2017.

\begin{abstract}
Binur R, Pancoro A. 2017. Inbreeding depression level of post-larvae freshwater prawn (Macrobrachium rosenbergii) from several hatcheries in Java, Indonesia. Biodiversitas 18: 609-618. Inbreeding accumulation will tend to reduce genetic variation or depressed of the prawn fry produced. This problem has caused a decrease in production and quality of prawns culture in Indonesia. The purpose of this study is to measure the level of inbreeding depression prawn fry generated from several hatcheries in Java by microsatellite markers. There is four microsatellite locus to be used i.e Prk9A/T1, Prk4G/T1, TGFP16, and Mr8-88. The amplification of fourth locus using PCR with 6-carboxy-fluorescine (6-FAM) label. The number of alleles (Na) from fourth locus is Mr8-88 (11 alleles), TGFP16 (10 alleles), Prk4G/T1 (9 alleles), dan Prk9A/T1 (5 alleles), respectively. The level of polymorphism locus from highest to lowest is locus Prk4G/T1 (0.703), Prk9A/T1 (0.507), TGFP16 (0.410), and Mr8-88 (0.370), respectively. Inbreeding depression level of postlarvae (PL) M. rosenbergii tend to moderate with BBI Ciamis (He 0.444), BBUG Samas (He 0.514), LRPTBPAT Sukamandi (He 0.519), and UPBL Probolinggo (He 0.530), respectively. AMOVA analysis showed about $8.0 \%$ genetic variation among populations. From these results, it can be concluded that the PL produced indicated have been depressed. Post-larvae prawns produced from fourth hatcheries is not recommended to be a broodstock but can be used for cultivation for farmers.
\end{abstract}

Keywords: Freshwater prawn, Macrobrachium rosenbergii, post-larvae, microsatellite, inbreeding depression, heterozygosity, genetic diversity

\section{INTRODUCTION}

Giant freshwater prawns Macrobrachium rosenbergii (De Man, 1879) is a native species freshwater prawn from Indonesia, which has the largest body size among other freshwater prawn species. The total body length of adult male up to $320 \mathrm{~mm}$ and female $250 \mathrm{~mm}$ with weight more

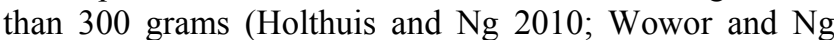
2007). Therefore, this shrimp has a high economic value and very liked by farmers. The high economic value of shrimp was not the increasing production of prawns in Indonesia. Most of the production of traditional catch prawns has declined every year. According to FAO (2012) Indonesia is the country with the largest natural catching is 5,460 tons/year. To reduce this catch, the government began improving prawns farming.

Based on data FAO (1998-2007) Indonesian prawn culture production is relative low, approximately 688.83 tons/year or $0.43 \%$ of the average global production (161,666 tons/year) (New 2010). Though Indonesia has a very wide farming land involving marine and coastal area covers 5.8 million $\mathrm{km}^{2}$ and 5.4 million hectares of inland waters are potential prawns culture (Saifuddin 2008). One major problem for farmers is not the availability of highquality fries. The increasing market has causing increased demand for fries. To meet this demand then some hatchery in Java to make the breeding program. Its good program must be avoided is inbreeding depression (Gjerde 2005) because will be reducing genetic variation or heterozygosity of the prawn populations (Sonesson et al. 2005).

Center of prawn culture in Indonesia mostly located in Java include West Java, Central Java, Yogyakarta and East Java. Outside Java prawns culture in Bali and Nusa Tenggara Barat (NTB). In Java, Yogyakarta has the highest production than other provinces. But Bali had the largest national production up to 742 tons in 2010 . If compared with the extent of land culture in Java, this indicates that the production of prawns in Java is having problems. Good breeding programs should avoid the depression of fries produced.

Genetically, this phenomenon is the main trigger of declining production and quality of shrimp produced. Inbreeding depression is an effect of the breeding accumulation conducted within the same population. This effect will reduce genetic variation or heterozygosity of fry produced, because for traits with dominant inheritance was expected heterozygotes to be equal or better than one or both of the homozygotes. Inbreeding depression leads primarily to a reduction of the mean phenotypic value shown by characters connected with reproductive capacity (fecundity, egg size, hatchability) or physiological efficiency (fry deformities, growth rate, survival) (Gjerde 2005; Sonesson et al. 2005).

This phenomenon has been shown from the decrease in the weight of prawns produced by farmers in Indonesia within a certain period. Then, was 2012 by $80 \%$ of prawn 
cultivation in Java (West Java, Central Java, Yogyakarta, East Java) infected disease Macrobrachium Nodavirus (MrNV). This caused farmers losing and threaten national production target of 10 tons/day. These problems may be related to prawn fry used by farmers that experienced depression or reduced of heterozygosity.

The level of depression postlarvae (PL) prawns was analyzed with microsatellite markers. Microsatellites markers also are known as simple sequence repeats (SSRs) or short tandem repeats (STRs) are stretches of DNA that consist of tandem repeats of 1-6 base pairs (Freeland 2005). This marker has several advantages compared other markers (Allozyme, RAPD, AFLP, mtDNA, RFLP). The advantages include: (i) co-dominant markers are the ability to distinguish between homozygotes and heterozygotes (Freeland 2005); (ii) They have been found in gene coding regions, introns, and in the non-gene sequences (Liu and Cordes 2004); (iii) have a high polymorphism (Hancock 1999) shown the value of the polymorphic information content (PIC) (Liu and Cordes 2004); and (iv) easily analyzed by PCR because it has a small fragment size 1-6 base pairs (Chistiakov et al. 2006; Liu and Cordes 2004).

Therefore, this study aims to determine scientifically whether prawn fry generated from several hatcheries in Java have been depressed (low heterozygosity) or not. Then how high depression that occurs in each population was collected.

\section{MATERIALS AND METHODS}

\section{Collecting samples}

Post-larvae (PL) prawns were collected from four hatcheries in Java from a different generations i.e: (i) Loka Riset Pemuliaan dan Teknologi Budidaya Perikanan Air Tawar (LRPTBPAT) Sukamandi, West Java (F11); (ii) Balai Benih Ikan (BBI) Ciamis, West Java (F5); (iii) Balai Benih Udang Galah (BBUG) Samas, Yogyakarta (F2); and (iv) Unit Pengelolah Budidaya Laut (UPBL) Probolinggo, East Java (F2). From each location was collected is 24 individual. Samples were stored in a refrigerator $\left(-80{ }^{\circ} \mathrm{C}\right)$ until used for extraction.

\section{DNA extraction}

DNA Extraction with the Wizard $^{\circledR}$ Genomic DNA Purify Kit (Promega) following the product protocol.
Extraction using pleopod muscle tissue (20-30 mg) was assisted with liquid nitrogen. DNA extracted electrophoresed with $1.5 \%$ agarose gel at a voltage of 100 volts (15 min.). DNA visualize by ethidium bromide (EtBr) for 5-10 min. A DNA purity levels were measured with a spectrophotometer (Ultraspec ${ }^{\circledR}$ Pharmacia-Biotech).

\section{Primers design}

Primer design using Bioinformatics approach with PCR product range 100-400 base pairs (bp) by Software Geneious Pro version 6.0.6 (http://www.geneious.com) (Table 1). Primer specificity was tested by BLAST primer NCBI (http://www.ncbi.nlm.nih.gov/tools/primer-blast/) and the secondary structure with DNA calculator (http://www.oligoevaluator.com). At the end of the 5' forward primer added universal primer (M13) (TGTAAAACGACGGCCAGT) according to the method Schulke (2000).

\section{PCR}

PCR followed the method Schuelke (2000) with slight modifications. PCR using M13 universal primers were labeled with 6-carboxy-fluorescine (6-FAM). The composition of the PCR $(20 \mathrm{~mL})$, that is: $2 \mathrm{~mL}$ dNTPs $(0.2$ $\mathrm{mM}) ; 2 \mathrm{~mL}$ Buffer $(0.5 \mathrm{x}) ; 0.25 \mathrm{~mL}$ forward primer $(0.125$ $\mu \mathrm{M})$; $1 \mathrm{~mL}$ reverse primer $(0.5 \mu \mathrm{M}) ; 1 \mathrm{~mL}$ FAM $+6-\mathrm{M} 13$ universal primers $(0.5 \mu \mathrm{M}) ; 1.6 \mathrm{MgCl}_{2}(2 \mathrm{mM}) ; 0.1 \mathrm{~mL}$ Dream tag $(0.5$ units $/ \mathrm{mL}) ; 1 \mathrm{~mL}$ of genomic DNA $(2.5$ $\mathrm{ng} / \mathrm{mL}$ ); $0.6 \mathrm{~mL}$ of DMSO; and $10.45 \mathrm{~mL}$ ddH20 (Deion). PCR performed in Thermal cycler machine AB Veriti ${ }^{\circledR}$ 96-Well. PCR performed pre-denaturation $94^{\circ} \mathrm{C}$ (5 min.), continued with 38 cycles denaturation at $94^{\circ} \mathrm{C}(30 \mathrm{sec}$.), annealing ( $30 \mathrm{sec})$, elongation at $72^{\circ} \mathrm{C}$ (45 sec.), and final elongation at $72^{\circ} \mathrm{C}(10 \mathrm{~min})$. PCR electrophoresed using $1.5 \%$ agarose at voltage 100 volts $(30 \mathrm{~min}$.). Visualization of DNA bands with Ethidium Bromide (EtBr) (5-10 min.).

\section{Data analysis}

Fragment analysis using the services of Macrogen, Inc. (Korea) (http://www.macrogen.com) with the ABI 3730xl sequencer. Electropherograms were analyzed by Software GenMarker version 2.2 (http://www.softgenetics.com). Allele frequency was calculated by Software GenAlEx version 6.41 (http://biology-assets.anu.edu.au) (Hamilton 2009; Peakall and Smouse 2009; 2012) with the equation:

Table 1. Primers used for amplification of microsatellite loci

\begin{tabular}{|c|c|c|c|c|c|c|}
\hline Locus & GenBank Acc No. & Primer sequence (5'-3') & Size (bp) & $\operatorname{Tm}\left({ }^{\circ} \mathbf{C}\right)$ & Motif & $T_{a}\left({ }^{0} \mathrm{C}\right)$ \\
\hline \multirow[t]{2}{*}{ Prk4G/T1 } & DQ019868 & F: TGCCAGCCACATGCTACTGCT & 21 & 58.76 & $(\mathrm{AGC})_{13}$ & 65.2 \\
\hline & & R: AGGGAAAGAGCGCACGCACG & 20 & 60.32 & & \\
\hline \multirow[t]{2}{*}{ Prk9A/T1 } & DQ019869 & F: CGGGATGGGAGCGAGGGTGA & 20 & 60.04 & $(\mathrm{CTG})_{7}$ & 69.0 \\
\hline & & R: CCGCACGGCATTCCTCAGCA & 20 & 60.04 & & \\
\hline \multirow[t]{2}{*}{ TGFP16 } & HQ722922 & F: TCGCTCCTCCATACGTCAACCCA & 23 & 59.44 & $(\mathrm{GT})_{22}$ & 64.5 \\
\hline & & R: AACCAAAGCCAGTGTGCCGT & 20 & 57.29 & & \\
\hline \multirow[t]{2}{*}{ Mr8-88 } & EU847622 & F: TGTGTGCACTTACTGTATTCCTCTCGC & 27 & 58.93 & $(\mathrm{AC})_{25}$ & 66.8 \\
\hline & & R: TGCССTCTGCCCACCACGTA & 20 & 59.82 & & \\
\hline
\end{tabular}

Note: forward primer $(\mathrm{F})$, reverse primer $(\mathrm{R})$, melting temperature $(\mathrm{Tm})$, annealing temperature $\left(T_{a}\right)$ 


$$
\text { FreqAllele }(p)=\frac{2 N x x+N x y}{2 N}
$$

Nxx is the number of alleles homozygous ( $x x), N x y$ is the number of alleles heterozygous (xy), and $\mathrm{N}$ is the samples number.

The level of polymorphism loci measured by the value of polymorphic information content using equation Botstein et al. (1980) with Software Cervus version 3.0.7 (http://www.fieldgenetics.com) with the equation:

$$
P I C=1-\left(\sum_{i=1}^{k} p_{i}^{2}\right)-2 \sum_{i=1}^{k-1} \sum_{j=i+1}^{k} 2 p_{i}^{2} p_{j}^{2}
$$

$k$ is the number of alleles, $p i$ and $p j$ is the frequency of allele from two populations $i$ and $j$. For data codominant, if value $>0.75$ then the locus is very informative. If the value between $0.5-0.75$ then the locus is informative and if the value of $<0.5$ is less informative.

Levels of inbreeding depression of each population are determined by the value of heterozygosity, including the number of effective alleles (Ne), observed heterozygosity (Ho) and expected heterozygosity (He) with Software GenAlEx version 6.41. To determine whether there is a significant difference between the value of Ho and He then tested with the Chi-square $\left(\chi^{2}\right)$ (p 0.05) (Hamilton 2009) with the equation:

$$
\chi^{2}=\sum \frac{(H o-H e)^{2}}{H e}
$$

Degrees of freedom (df) is $\mathrm{k}-1, \mathrm{k}=$ number of loci. If the $\chi^{2}>\chi^{2}$ table $(0.05)$ or $p>0.05$, then there is a significant difference between Ho and He. Conversely, if the $\chi^{2}<\chi^{2}$ table $(0.05)$ or $\mathrm{p}<0.05$ there is no significant difference between the value of Ho and He.

Fixation index $(\mathrm{F})$ or inbreeding coefficient is analyzed with Software GenAlEx version 6.41 (Peakall and Smouse 2009) with the equation:

$$
F=\frac{H e-H o}{H e}
$$

Fixation index values between -1 to +1 . If the value is close to zero, its indicates the occurrence of random mating. The value +1 indicates the occurrence of inbreeding or not detection of null alleles. The value of -1 indicates excess heterozygotes.

Genetic variation between populations is determined by genetic distance, include analysis of analysis of molecular variance (AMOVA) and principal coordinates analysis (PCA) with Software GenAlEx version 6.41. AMOVA analysis based on statistical PhiPT (Peakall and Smouse $2009 ; 2012$ ). If the value PhiPT $=0$ then there is no genetic difference between populations. If the value PhiPT $>0$ then there are genetic differences between populations. Dendrogram constructed based on Nei's genetic distance (1978) using the UPGMA method with Software POPGENE version 1.32 (https://sites.ualberta.ca/ fyeh/popgene_ info.html) (Yeh et al. 1999).

\section{RESULTS AND DISCUSSION}

\section{PCR and fragment analysis}

PCR results from four loci (Prk9A/T1, Prk4G/T1, TGP16, Mr8-88) showed bands size more than 250 base pairs (bp). Locus Prk9A/T1 and Mr 8-88 has a thick band with the size 302 and $248 \mathrm{bp}$. Then the locus Prk4G/T1 and Mr8-88 has two thick bands of different sizes, i.e., 228, 232 and 262, $264 \mathrm{bp}$ indicating the presence of two alleles (Figure 1).

The results of the fragment analysis indicate allele size between 160-306 bp. The largest size range of alleles at the locus TGFP16 (162-306 bp) and the smallest at the locus Prk4G/T1 (160-232 bp) (Table 2). The number of alleles that were found from each locus is MR8-88 (11 alleles), TGFP16 (10 alleles), Prk4G/T1 (9 alleles), and Prk9A/T1 (5 alleles). Series of alleles of each locus is MR8-88 (160, $161,162,247,248,249,256,258,263,266,282$ bp), TGFP16 (162, 163, 252, 260, 262, 264, 265, 269, 292, 306 bp), Prk4G/T1 (160, 161, 162, 223, 224, 227, 228, 231, 232 bp), and Prk9A/T1 (162, 163, 293, 302, 305 bp). In the four loci analyzed the presence of null alleles or alleles were not detected. Some samples had high stutter band with intensity $80 \%$ of the major allele.

The number of heterozygous alleles and homozygous that were found at each locus varied. The highest number of alleles observed in heterozygous loci Prk9A/T1 (82 alleles) and lowest in TGFP16 loci (15 alleles) while the highest number of homozygous alleles found in TGP16 loci (81 alleles) and lowest in Prk9A/T1 loci (14 alleles). Population LRPTBPAT Sukamandi (F11) has the highest number of heterozygous alleles (45 alleles) while the largest homozygous alleles found in the population UPBL Probolinggo (62 alleles).

\section{Allele frequency}

Prk9A/T1 locus had the highest frequency in allele 302 (average 57.3\%), Prk4G/T1 in allele 161 (average 47.9\%), TGFP16 at in allele 163 (average 72.4\%), and MR8-88 in allele 160 (average 77.6\%) (Table 3). The population of LRPTBPAT Sukamandi and BBI Ciamis has the highest frequency of allele 160 (MR8-88), respectively $87.5 \%$ and $97.9 \%$. The population of BBUG Samas and UPBL Probolinggo has the highest frequency in allele 163 (TGFP16), respectively $79.2 \%$ and $83.3 \%$ while the lowest allele frequency of each population is $0.21 \%$ which is spread all loci (Figure 2).

Table 2. Allele size range of each locus

\begin{tabular}{llc}
\hline Locus & Motif/Repeats & Allele size (bp) \\
\hline Prk9A/T1 & $(\mathrm{CTG})_{7}$ & $162-305$ \\
Prk4G/T1 & $(\mathrm{AGC})_{13}$ & $160-232$ \\
TGFP16 & $(\mathrm{GT})_{22}$ & $162-306$ \\
Mr8-88 & $(\mathrm{AC})_{25}$ & $160-282$ \\
\hline
\end{tabular}



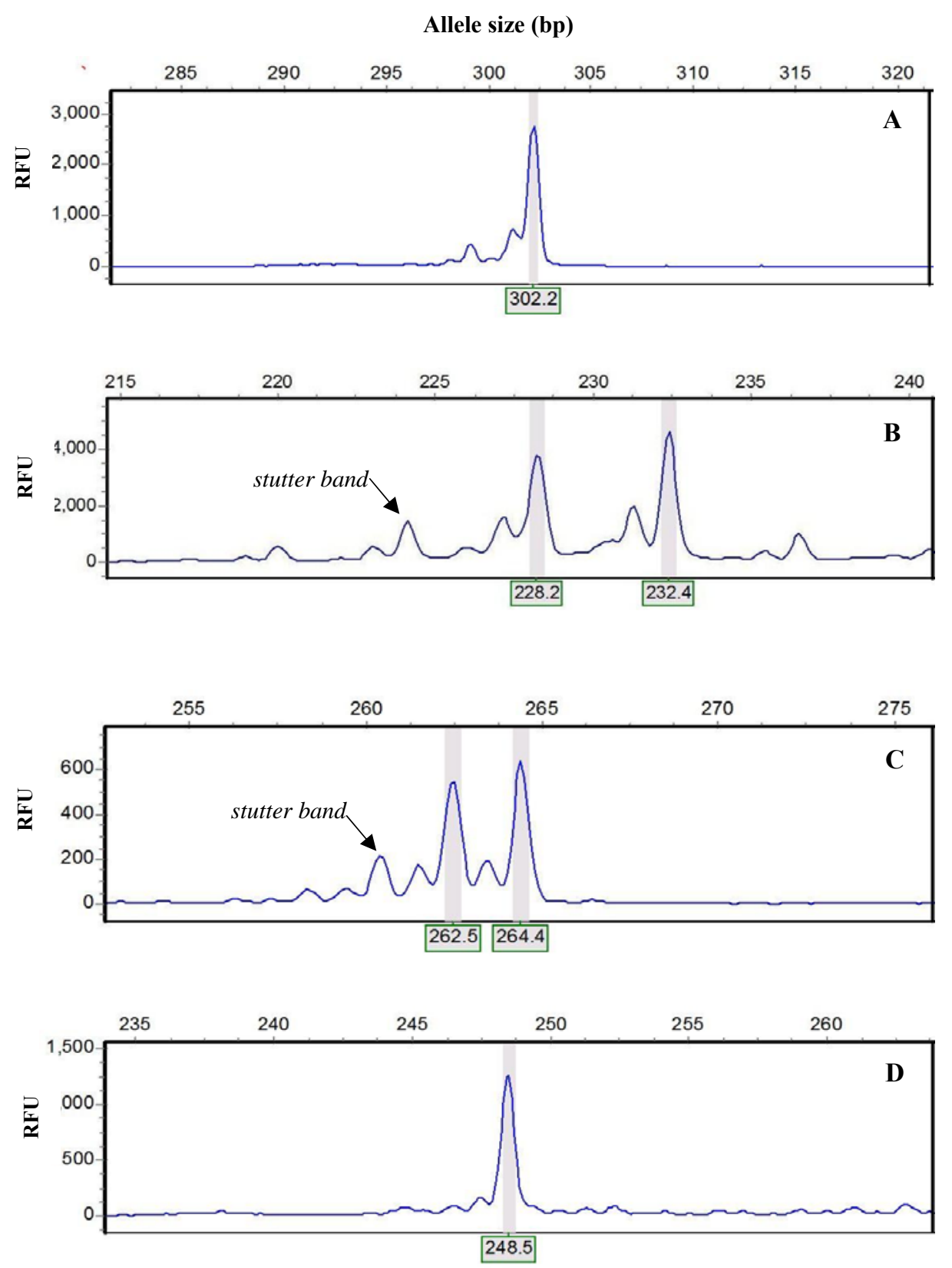

Figure 1. Examples of electropherogram from four loci. A. Allele homozygotes (302) at Prk9A/T1 locus, B. Heterozygous alleles (228; 232) at Prk4G/T1 locus, C. Heterozygous alleles $(262 ; 264)$ at TGFP16 locus, and D. Allele homozygotes (248) at the MR8-88 locus. Relative fluorescence units (RFU); stutter bands are small peaks resulting from slipped strand during the PCR process

\section{Locus polymorphism}

Polymorphism of each locus is calculated based on the value of the PIC. The highest values are at Prk4G/T1 loci (0.703) and lowest in the locus MR8-88 (0.370). Locus Prk9A/T1 and Prk4G/T1 can be used for further microsatellite analysis because it has a moderate value of the PIC (Table 4).

\section{Inbreeding depression levels}

The level of inbreeding depression is measured by the value of heterozygosity (Ho and He). Value heterozygosity of each population can not be compared because on different generations. Heterozygosity values between populations have a narrow range, where the average values Ho ranged from 0.354 to 0.469 while He from 0.444 to 0.530 . Ho values from high to lowest that is population of Sukamandi LRPTBPAT (0.469), BBUG Samas (0.438), BBI Ciamis (0.417), and UPBL Probolinggo (0.354) while the value He high to lowest that are UPBL Probolinggo (0.530), LRPTBPAT Sukamandi (0.519), BBUG Samas (0.514), and BBI Ciamis (0.444) populations (Table 5). Overall heterozygosity values of the four population tend to be moderate. According to Frankham et al. (2002) if He values between 0.60 to 0.80 the population has a high value of genetic diversity. This shows that the four populations indicate depressed especially populations of the BBI Ciamis. 
Locus Prk9A/T1

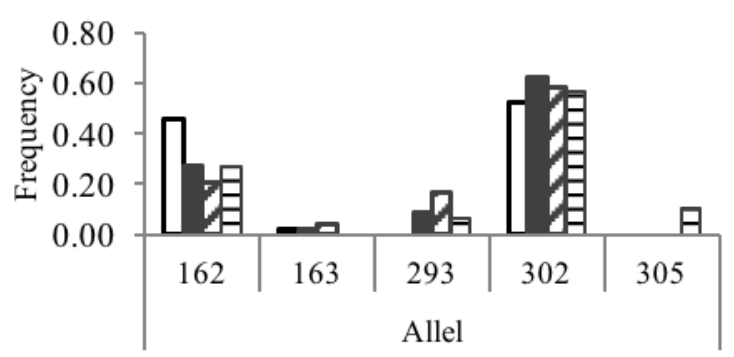

$\boldsymbol{口}_{\mathrm{A}} \boldsymbol{\nabla} \boldsymbol{\mathrm { B }}$ 日

Locus Prk4G/T1

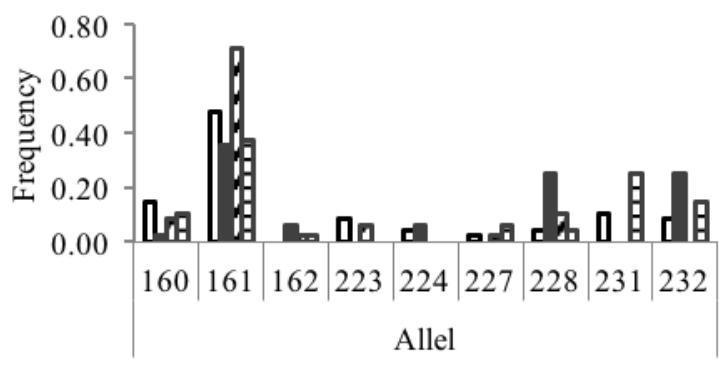

$\boldsymbol{口}_{\mathrm{A}} \boldsymbol{B}_{\mathrm{B}} \boldsymbol{\mathrm { B }} \mathrm{D}$
Locus TGFP16

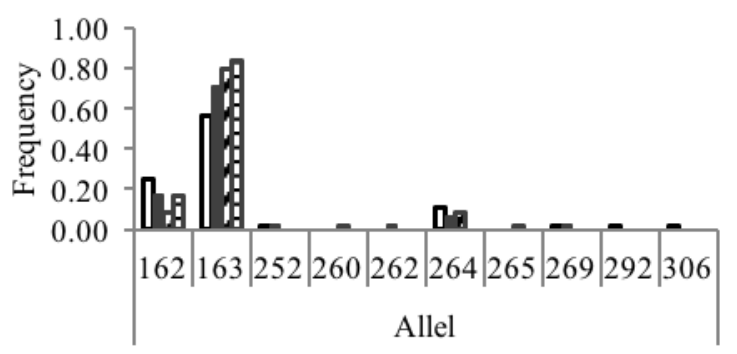

$\boldsymbol{口}_{\mathrm{A}} \boldsymbol{B}_{\mathrm{B}} \boldsymbol{口}_{\mathrm{D}}$

Locus Mr88-8

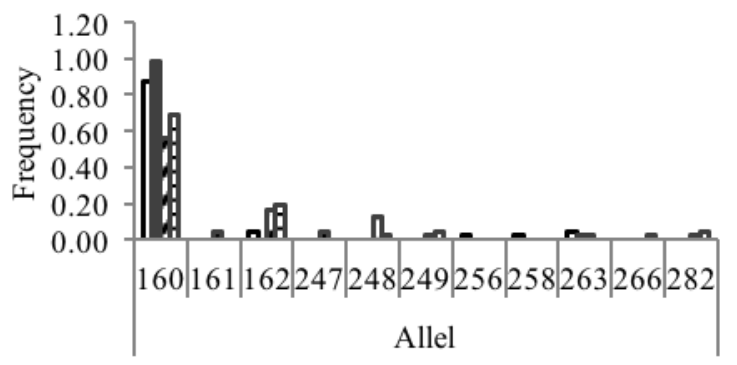

$\boldsymbol{口}_{\mathrm{A}} \boldsymbol{\nabla} \boldsymbol{\mathrm { B }} \boldsymbol{\mathrm { D }}$

Figure 2. Allele frequencies histograms of each locus. A. LRPTBPAT Sukamandi (F11), B. BBI Ciamis (F5), C. BBUG Samas (F2), and D. UPBL Probolinggo (F2)

Fixation index (F) of the four populations tend to be close to zero, with average values between 0.070 to 0.424 . The highest fixation index values in UPBL Probolinggo population (0.424) while the lowest value in BBI Ciamis population (0.070). Of the range of values indicates that the parent of four populations experiencing random mating. Significance test (Chi-square, $\chi^{2}$ ) between $\mathrm{Ho}$ and $\mathrm{He}$ values indicate that the population of BBUG Samas, BBI Ciamis, and LRPTBPAT Sukamandi did not differ significantly $(p<0.05)$ while the population of UPBL Probolinggo differs significantly $(\mathrm{p}>0.05)$. This suggests that the population of Probolinggo UPBL deficient values observed heterozygosity (Ho) (Table 6).

\section{Genetic variation among populations}

Analysis of AMOVA (Analysis of Molecular Variance) based on allele frequencies showed the value of genetic variation between populations by $8 \%$ while the variation within populations by $92 \%$ (Table 7 ). This indicates the genetic variation of four populations (LRPTBPAT Sukamandi, BBI Ciamis, BBUG Samas, and UPBL Probolinggo) are relatively similar. UPGMA dendrogram showed two population groups, are (1) population from UPBL Probolinggo and (2) population from LRPTBPAT Sukamandi, BBI Ciamis, and BBUG Samas.
The population of LRPTBPAT Sukamandi has close genetic relationship with populations BBI Ciamis (0.842) (Figure 3 ). The closeness of the genetic relationship of the two populations indicates that the two populations have similar origin broodstock, while the population of UPBL Probolinggo shows different broodstock origin of all three populations. The results of principal coordinates analysis (PCA) showed the genetic distribution among individuals from four populations sufficiently dispersed in all quadrants. However, most tend to cluster and overlap in quadrants two and three (Figure 4). This indicates that individuals from four populations have a close genetic relationship.

\section{Discussion}

Agarose electrophoresis often shows a lack of good results for microsatellite fragment analysis because of a large pore size. This weakness causes a small microsatellite fragment was not detected on the gel so that the resolution of the resulting bands is relatively low. However, the use of agarose is helpful in confirming the successful amplification because of the low cost. According to Wang et al. (2009), a gel is good to use the metaphor agarose at a concentration of at least 3\% and polyacrylamide (PAGE) with a concentration of $10 \%$. Polyacrylamide gel to detect 
the allele size smaller (5-500 bp) compared to agarose (50$20.000 \mathrm{bp}$ ) so it has a better accurate (Sambrook et al. 1989). To resolve this problem, the PCR using primers labeled with a fluorescent dye or markers (Shimizu et al. 2002). This dye is a chemical can fluoresce when fragment analyzed by laser light or automated sequencer. There are four commonly used dyes, i.e., 6-carboxy-fluorescine (FAM), hexachloro-6-carboxy-fluorescine (HEX), 6carboxy-X-rhodamine (ROX), and tetrachloro-6-carboxyfluorescine (TET) (Schulke 2000). The fourth marker will give a different color when given light, where FAM blue, HEX green, ROX red, and TET yellow (Glenn 2001).

Stutter bands are artifacts product resulting from the events of slipped strand during the PCR process that microsatellite fragment produced has a different length. The slipped strand is also known as slip-strand mispairing (SSM) (Eisen 1999), polymerase slippage (Chistiakov et al. 2006; Liu and Cordes 2004) or replication slippage (Ellegren 2004). This slipped strand is generally caused by a mutation that occurs in a repeat sequence. The frequency of slipped strand during the PCR reaction for dinucleotide motifs (CA/GT)n and mononucleotide (A/T)n estimated to be about four to eight bases (Shinde et al. 2003).

Samples that have a stutter band is high $(>80 \%)$ of the dominant allele can make a mistake in scoring alleles, especially for the heterozygous allele (having two peaks). Dinucleotide motifs generally have high stutter bands when compared with the motif of tri, tetra, penta, and hexanucleotide. With the percentage of motif mono- $>90 \%$, di- $30-44 \%$, tri- $11-18 \%$, tetra- $<10 \%$, and penta- $<1 \%$ (Walsh et al. 2006).

In order to reduce stutter bands generated, it can be designed with the primary motive longer ie tri, tetra, penta, and hexanucleotide. Also, it can use that motive is not perfect (imperfect) eg (GTG) $)_{7} \mathrm{CTCTG}(\mathrm{GTG})_{8}$ and a mixture of motifs (compound) eg $(\mathrm{GTG})_{8}(\mathrm{AT})_{16}$ ) (Butler $2005)$. With both these methods can reduce the occurrence of slipped strand during DNA synthesis so that the resulting reduced stutter bands.

Lowest PIC value at the locus MR8-88 (0.370). The low value of the PIC is probably closely related to the motif used is (AC) $)_{25}$. According to Neff and Gross (2001) motif (AC)n in most vertebrate animals including shrimp are the main factors that affect the rate of mutation. Microsatellite mutation is usually a change in the base as well as the overall sequence repeated. These mutations can increase or decrease the polymorphism of a locus. But generally, mutations will tend to decrease the polymorphism of loci (Ellegren 2004).

Microsatellite mutation rate is high enough to reach $10^{-2}$ to $10^{-6}$ per locus per generation compared to other DNA sequences (Ellegren 2000; Liu and Cordes 2004). This mutation causes a microsatellite polymorphism tends to be high and varies between species (Chistiakov et al. 2006; Ellegren 2004; Liu and Cordes 2004). With these characteristics can be used as a powerful molecular marker to measure genetic diversity within populations (Liu and Cordes 2004).
Based on research Maryanto (2012) in wild-type giant prawns in Indonesia showed the locus Prk9A/T1 is very informative with PIC value of 0.830 . This indicates the locus Prk9A/T1 has decreased polymorphism of each generation produced. This decrease is influenced by breeding pressure causing alleles in some loci is reduced or lost. According to Freeland (2005) loss of some alleles or decrease genetic variation in populations is influenced by several factors: (i) genetic bottlenecks, (ii) genetic drift, (iii) natural selection, and (iv) reproduction (inbreeding or outbreeding).

Table 3. Allele frequency of each locus

\begin{tabular}{|c|c|c|c|c|c|}
\hline \multirow[b]{2}{*}{ Locus } & \multirow[b]{2}{*}{ Allele } & \multicolumn{4}{|c|}{ Frequency } \\
\hline & & $\begin{array}{l}\text { LRPTBPAT } \\
\text { Sukamandi }\end{array}$ & $\begin{array}{c}\text { BBI } \\
\text { Ciamis }\end{array}$ & $\begin{array}{l}\text { BBUG } \\
\text { Samas }\end{array}$ & $\begin{array}{c}\text { UPBL } \\
\text { Probolingog }\end{array}$ \\
\hline \multirow{5}{*}{ Prk9A/T1 } & 162 & 0.458 & 0.271 & 0.208 & 0.271 \\
\hline & 163 & 0.021 & 0.021 & 0.042 & 0.000 \\
\hline & 293 & 0.000 & 0.083 & 0.167 & 0.063 \\
\hline & 302 & 0.521 & 0.625 & 0.583 & 0.563 \\
\hline & 305 & 0.000 & 0.000 & 0.000 & 0.104 \\
\hline \multirow[t]{9}{*}{ Prk4G/T1 } & 160 & 0.146 & 0.021 & 0.083 & 0.104 \\
\hline & 161 & 0.479 & 0.354 & 0.708 & 0.375 \\
\hline & 162 & 0.000 & 0.063 & 0.021 & 0.021 \\
\hline & 223 & 0.083 & 0.000 & 0.063 & 0.000 \\
\hline & 224 & 0.042 & 0.063 & 0.000 & 0.000 \\
\hline & 227 & 0.021 & 0.000 & 0.021 & 0.063 \\
\hline & 228 & 0.042 & 0.250 & 0.104 & 0.042 \\
\hline & 231 & 0.104 & 0.000 & 0.000 & 0.250 \\
\hline & 232 & 0.083 & 0.250 & 0.000 & 0.146 \\
\hline \multirow[t]{10}{*}{ TGFP16 } & 162 & 0.250 & 0.167 & 0.083 & 0.167 \\
\hline & 163 & 0.563 & 0.708 & 0.792 & 0.833 \\
\hline & 252 & 0.021 & 0.021 & 0.000 & 0.000 \\
\hline & 260 & 0.000 & 0.000 & 0.021 & 0.000 \\
\hline & 262 & 0.000 & 0.021 & 0.000 & 0.000 \\
\hline & 264 & 0.104 & 0.063 & 0.083 & 0.000 \\
\hline & 265 & 0.000 & 0.000 & 0.021 & 0.000 \\
\hline & 269 & 0.021 & 0.021 & 0.000 & 0.000 \\
\hline & 292 & 0.021 & 0.000 & 0.000 & 0.000 \\
\hline & 306 & 0.021 & 0.000 & 0.000 & 0.000 \\
\hline \multirow[t]{11}{*}{ Mr88-8 } & 160 & 0.875 & 0.979 & 0.563 & 0.688 \\
\hline & 161 & 0.000 & 0.000 & 0.042 & 0.000 \\
\hline & 162 & 0.042 & 0.000 & 0.167 & 0.188 \\
\hline & 247 & 0.000 & 0.000 & 0.042 & 0.000 \\
\hline & 248 & 0.000 & 0.000 & 0.125 & 0.021 \\
\hline & 249 & 0.000 & 0.000 & 0.021 & 0.042 \\
\hline & 256 & 0.021 & 0.000 & 0.000 & 0.000 \\
\hline & 258 & 0.021 & 0.000 & 0.000 & 0.000 \\
\hline & 263 & 0.042 & 0.021 & 0.021 & 0.000 \\
\hline & 266 & 0.000 & 0.000 & 0.000 & 0.021 \\
\hline & 282 & 0.000 & 0.000 & 0.021 & 0.042 \\
\hline
\end{tabular}

Table 4. PIC (Polymorphic Information Content) value of each population

\begin{tabular}{lllll}
\hline Locus & N & Na & PIC & Category \\
\hline Prk9A/T1 & 96 & 5 & 0.507 & Moderate \\
Prk4G/T1 & 96 & 9 & 0.703 & Moderate \\
TGFP16 & 96 & 10 & 0.410 & Low \\
Mr8-88 & 96 & 11 & 0.370 & Low \\
\hline
\end{tabular}

Note: high $>0.75$, moderate 0.50 to 0.75 , low $<0.50$ 
Table 5. Value of genetic diversity (heterozygosity) from each population

\begin{tabular}{|c|c|c|c|c|c|}
\hline \multirow{2}{*}{ Populations } & \multicolumn{5}{|c|}{ Locus } \\
\hline & Prk9A/T1 & Prk4G/T1 & TGFP16 & Mr8-88 & Mean \\
\hline \multicolumn{6}{|c|}{ LRPTBPAT Sukamandi (F11) } \\
\hline$N$ & 24 & 24 & 24 & 24 & $24 \pm 0.000$ \\
\hline $\mathrm{Na}$ & 3 & 8 & 7 & 5 & $5.750 \pm 1.109$ \\
\hline $\mathrm{Ne}$ & 2.076 & 3.578 & 2.554 & 1.299 & $2.377 \pm 0.477$ \\
\hline Ho & 0.958 & 0.500 & 0.250 & 0.167 & $0.469 \pm 0.178$ \\
\hline $\mathrm{He}$ & 0.518 & 0.720 & 0.609 & 0.230 & $0.519 \pm 0.105$ \\
\hline$F$ & -0.849 & 0.306 & 0.589 & 0.275 & $0.080 \pm 0.318$ \\
\hline \multicolumn{6}{|c|}{ BBI Ciamis (F5) } \\
\hline$N$ & 24 & 24 & 24 & 24 & $24 \pm 0.000$ \\
\hline $\mathrm{Na}$ & 4 & 6 & 6 & 2 & $4.500 \pm 0.957$ \\
\hline $\mathrm{Ne}$ & 2.122 & 3.866 & 1.870 & 1.043 & $2.225 \pm 0.594$ \\
\hline Ho & 0.750 & 0.750 & 0.125 & 0.042 & $0.417 \pm 0.193$ \\
\hline $\mathrm{He}$ & 0.529 & 0.741 & 0.465 & 0.041 & $0.444 \pm 0.147$ \\
\hline$F$ & -0.419 & -0.012 & 0.731 & -0.021 & $0.070 \pm 0.240$ \\
\hline \multicolumn{6}{|c|}{ BBUG Samas (F2) } \\
\hline$N$ & 24 & 24 & 24 & 24 & $24 \pm 0.000$ \\
\hline $\mathrm{Na}$ & 4 & 6 & 5 & 8 & $5.750 \pm 0.854$ \\
\hline $\mathrm{Ne}$ & 2.420 & 1.907 & 1.559 & 2.743 & $2.157 \pm 0.263$ \\
\hline Ho & 0.833 & 0.208 & 0.250 & 0.458 & $0.438 \pm 0.143$ \\
\hline $\mathrm{He}$ & 0.587 & 0.476 & 0.359 & 0.635 & $0.514 \pm 0.062$ \\
\hline$F$ & -0.420 & 0.562 & 0.303 & 0.279 & $0.181 \pm 0.210$ \\
\hline \multicolumn{6}{|c|}{ UPBL Probolinggo (F2) } \\
\hline$N$ & 24 & 24 & 24 & 24 & $24 \pm 0.000$ \\
\hline $\mathrm{Na}$ & 4 & 7 & 2 & 6 & $4.750 \pm 1.109$ \\
\hline $\mathrm{Ne}$ & 2.472 & 4.144 & 1.385 & 1.953 & $2.488 \pm 0.595$ \\
\hline Ho & 0.875 & 0.375 & 0.000 & 0.167 & $0.354 \pm 0.190$ \\
\hline $\mathrm{He}$ & 0.595 & 0.759 & 0.278 & 0.488 & $0.530 \pm 0.101$ \\
\hline$F$ & -0.469 & 0.506 & 1.000 & 0.658 & $0.424 \pm 0.315$ \\
\hline \multicolumn{6}{|l|}{ Total (Mean) } \\
\hline$N$ & 96 & 96 & 96 & 96 & $96 \pm 0.000$ \\
\hline $\mathrm{Na}$ & 3.750 & 6.750 & 5.000 & 5.250 & $5.188 \pm 0.476$ \\
\hline $\mathrm{Ne}$ & 2.272 & 3.374 & 1.842 & 1.759 & $2.312 \pm 0.226$ \\
\hline Ho & 0.854 & 0.458 & 0.156 & 0.208 & $0.419 \pm 0.080$ \\
\hline $\mathrm{He}$ & 0.557 & 0.674 & 0.428 & 0.349 & $0.502 \pm 0.049$ \\
\hline$F$ & -0.539 & 0.341 & 0.656 & 0.298 & $0.189 \pm 0.128$ \\
\hline
\end{tabular}

Note: number of samples $(\mathrm{N})$, number of alleles $(\mathrm{Na})$, number of effective alleles $(\mathrm{Ne})$, observed heterozygosity (Ho), expected heterozygosity (He), fixation index (F)

Table 6. Significance test (Chi-square, $\chi 2)$ between Ho and He values of the four populations

\begin{tabular}{|c|c|c|c|c|c|}
\hline \multirow{2}{*}{ Populations } & \multicolumn{2}{|c|}{ Heterozygosity } & \multirow[b]{2}{*}{ df } & \multirow{2}{*}{$\chi^{2}$} & \multirow{2}{*}{$\chi_{(0.05)}^{2}$} \\
\hline & Ho & $\mathrm{He}$ & & & \\
\hline LRPTBPAT Sukamandi (F11) & 0.469 & 0.519 & 3 & 0.669 & 7.814 \\
\hline BBI Ciamis (F5) & 0.417 & 0.444 & 3 & 0.341 & 7.814 \\
\hline BBUG Samas (F2) & 0.438 & 0.514 & 3 & 0.336 & 7.814 \\
\hline UPBL Probolinggo (F2) & 0.354 & 0.530 & 3 & $0.815^{*}$ & 7.814 \\
\hline
\end{tabular}

Note: $\mathrm{df}=$ degrees of freedom, ${ }^{*}$ significant $(\mathrm{p}>0,05)$

Table 7. The results of AMOVA analysis

\begin{tabular}{lllcclc}
\hline Source & df & SS & MS & Est. Var. & \% & Value PhiPT \\
\hline Among populations & 3 & 23.083 & 7.694 & 0.219 & $8 \%$ & 0.082 \\
Within populations & 92 & 224.417 & 2.439 & 2.439 & $92 \%$ & $100 \%$ \\
Total & 95 & 247.500 & & 2.658 & & \\
\hline
\end{tabular}

Note: sums of squares (SS), mean sums of squares (MS), estimates of variances (Est. Var) 


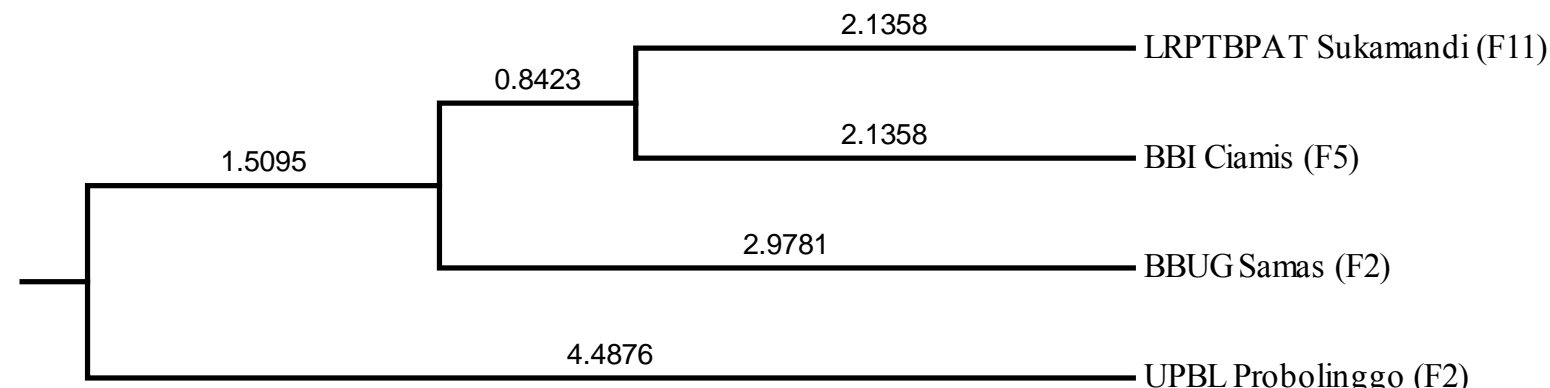

UPBL Probolinggo (F2)

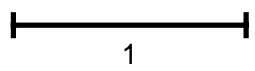

Figure 3. UPGMA dendrogram from the four populations based on Nei's genetic distance (1978). Dendrogram shows the population from Probolinggo UPBL separate from other groups (LRPTBPAT Sukamandi, BBI Ciamis, and BBUG Samas) while the population from LRPTBPAT Sukamandi and BBI Ciamis have close genetic distance (0.8423).

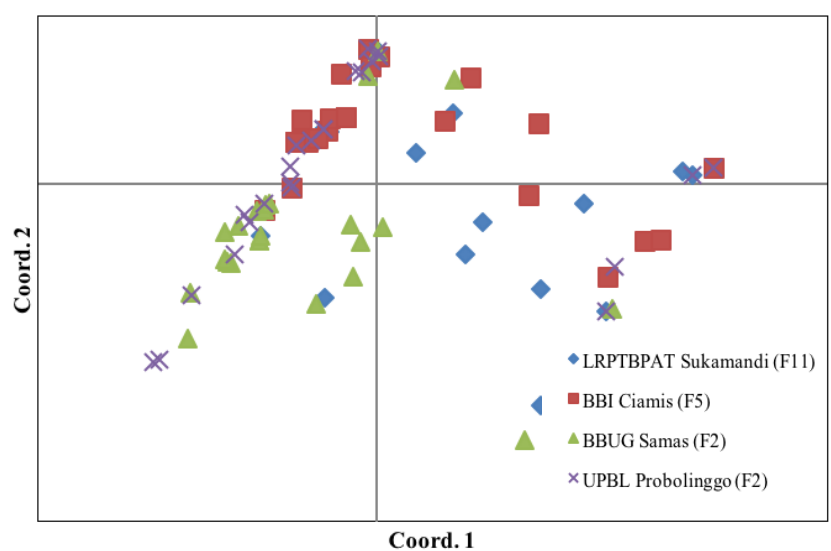

Figure 4. The results of the PCA analysis from four populations. Most of the individuals from four populations tend to cluster and overlap in quadrants two and three

Genetic bottlenecks will accelerate genetic drift in the population. The diversity of alleles in a population will usually decrease after the occurrence of genetic bottlenecks because of missing some alleles. Loss of this allele will cause the low value of He while the value of Ho may not be reduced or increased. Several studies have shown that population bottlenecks continuously (3-4 generations) may not have a genetic variation because it will continue to lose alleles (Freeland 2005).

Inbreeding does not change the frequency of alleles in a population, but increases the proportion of homozygous at all loci. So that, it can reduce the overall genetic diversity within populations based on the value of Ho though the value He has not changed. This decrease will reduce the rate of survival and reproduction of individuals. If allowed to continue would eliminate genetic diversity through increased mortality rate (Freeland 2005).

Based on the heterozygosity expectation value (He) population of BBUG Samas (F2) (0.514), UPBL Probolinggo (F2) (0.530), and BBI Ciamis (F5) (0.444) have been depressed because there is on the generation of F2 and F5 especially populations of BBI Ciamis. According to information from BBI Ciamis that broodstock used generally taken randomly from an enlargement absence of selection. So it is assumed this phenomenon affects decreasing genetic diversity of fries produced, while the heterozygosity expectation value of LRPTBPAT Sukamandi population (0.519) is stable because it is in the F11 generation. According to Gjerde (2005), if it is assumed the limited population by the rate of inbreeding $(\Delta \mathrm{F})$ of $0.5 \%$ or $1 \%$ per generation, the population tends to have genetic diversity that is stable at ten the future generation with a value $>0.60$. This stability is influenced by interbreeding or cross breeding were conducted with various strains of prawns i.e., Musi (South Sumatra), Barito (Borneo), Asahan (North Sumatra), and Ciasem (West Java) (Khasani et al. 2010). However, the fries produced from LRPTBPAT Sukamandi will continue to decline if it not done the turn of the new broodstock.

The occurrence of depression in prawn fries (post-larva) produced from the third hatcheries (BBI Ciamis, BBUG Samas, and UPBL Probolinggo) shown that the need to improvement genetic broodstock. The depression rate will continue to increase if further inbreeding is done. Genetic improvement is recommended to bring a new broodstock from wild that has a high genetic variation. Based on research Maryanto (2012) giants prawns from Jayapura Papua have a high genetic variation with He values greater than 0.80 . However, this study should be continued to other areas in Papua, which is likely to have a higher genetic variation. In addition, the population needs to continue to 
domestication obtained if used as a source for new broodstock.

Breeding program conducted continuously tends to decrease the genetic variation of prawns produced. This decrease could endanger further genetic improvement if not done regeneration or replacement broodstock (Gjerde 2005). Therefore, monitoring of genetic diversity in breeding programs is an important variable to do. Monitoring is recommended that in each generation produced so that it can be seen that a decrease in genetic variation occurs. This is very useful as a reference for regeneration or exchange broodstock genetically superior.

The population of UPBL Probolinggo has a significant difference between the value of Ho (0.354) and He (0.530). According to Freeland (2005) if the value of Ho is significantly lower than the value He then Wahlund effect is a decrease in the value of heterozygosity relative to $\mathrm{He}$ because of differences in allele frequencies between subpopulations or loci. This effect is influenced by several factors i.e., nonrandom mating, null alleles, natural selection or small populations.

Based on the analysis of the fixation index (F) shows that the four populations are experiencing random mating. These results are probably due to broodstock used results interbreeding between strains (GIMacro, Musi, Barito, Asahan, and Ciasem).

Based on AMOVA analysis showed the genetic variation of four populations is relatively similar. This result is influenced by broodstock strains used area from GIMacro and the result of cross breeding with other strains. Similar to the population of LRPTBPAT Sukamandi is the result of a cross between a female GIMacro and male Musi so that some loci have the same number and allele frequency. Based on information from the BBI Ciamis hatchery that used originally be obtained from hatchery LRPTBPAT Sukamandi because their location is not far. While the hatchery UPBL Probolinggo located far away from the three other hatcheries.

Based on the PCA analysis to increase genetic variation broodstock can be done through crossbreeding between populations that have different genetic variations. Crossbreeding can be done that is between populations of the BBI Ciamis with BBUG Samas or LRPTBPAT Sukamandi because it shows the genetic distribution in different quadrants.

In general, the fourth populations studied indicate depression $(\mathrm{He}<0.60)$ especially populations of the BBI Ciamis. For that, it is necessary to improvement genetic broodstock. Genetic improvement is recommended to bring a new broodstock from the wild. To bring in new broodstock, needed further research to obtain genetically superior broodstock especially the level of genetic variation. Based on research Maryanto (2012) giant prawns from Jayapura Papua has high levels of genetic variation than other regions in Indonesia (Sumatra, Borneo, and Sulawesi).

Having obtained the candidate new broodstock is necessary for domestication, so it can adapt to the new environment with better. Domestication is important to avoid stress and death of the broodstock so it can produce quality fries.

\section{ACKNOWLEDGEMENTS}

The author would like to thank the LRPTBPAT Sukamandi and BBI Ciamis, West Java as well as BBUG Samas, Yogyakarta and UPBL Probolinggo, East Java, Indonesia for donating the sample and Dr. Imron Nawawi and Ikhsan Khasani of hatchery LRPTBPAT Sukamandi on discussion and information.

\section{REFERENCES}

Botstein D, White RL, Skolnick M, Davis RW. 1980. Construction of a genetic linkage map in man using restriction fragment length polymorphisms. Hum Genet 32: 314-331.

Butler JM. 2005. Forensic DNA Typing Biology, Technology, and Genetics of STR Markers. Elsevier Academic Press, USA.

Chistiakov DA, Hellemans B, Volckaert FAM. 2006. Microsatellites and their genomic distribution, evolution, function and applications: a review with special reference to fish genetics. Aquaculture 255: 1-29.

Eisen JA. 1999. Mechanistic basis for microsatellite instability. In: Goldstein DB, Schlotterer C (eds) Microsatellites Evolution and Application. 2nd ed. Oxford Univ Press, Oxford.

Ellegren H. 2004. Microsatellites: Simple sequences with complex evolution. Nature Rev Genet 5: 435-445.

Frankham R, Ballou JD, Briscoe DA. 2002. Introduction to Conservation Genetics. Cambridge Univ Press, United Kingdom.

Freeland JR. 2005. Molecular Ecology. John Wiley and Sons Ltd, England.

Glenn TC. 2001. Directly Tagging PCR Primers with Fluorescent Dyes. Department of Biological Sciences University of South Carolina, Columbia.

Gjerde B. 2005. Design of breeding programs. In: Gjedrem T (eds) Selection and Breeding Programs in Aquaculture. Springer, Netherlands.

Hamilton MB. 2009. Population Genetics. 1st ed. John Wiley and Sons Ltd, United Kingdom.

Hancock JM. 1999. Microsatellites and other simple sequences: genomic context and mutational mechanisms. In: Goldstein DB, Schlotterer C (eds) Microsatellites Evolution and Application. 1st ed. Oxford Univ Press, Oxford.

Holthuis LB, Ng PKL. 2010. Nomenclature and taxonomy. In: New MB, Valenti WC, Tidwell JH, D'Abramo LR, Kutty MN (eds) Freshwater Prawns Biology and Farming. Wiley-Blackwell, United Kingdom.

Saifuddin. 2008. Indonesian Fisheries Book (IFB): Performance and Statistic of Indonesian Fisheries. Ministry of Marine Affairs and Fisheries (MMAF) and Japan International Cooperation Agency (JICA), Jakarta

Khasani I, Imron, Suprapto R, Himawan Y. 2010. Evaluate the performance of cross prawns (Macrobrachium rosenbergii) from multiple source populations. Prosiding Forum Inovasi Teknologi Akuakultur.

http://www.sidik.litbang.kkp.go.id/index.php/searchkatalog/byId/225 6 [Indonesian]

Liu ZJ, Cordes JF. 2004. DNA marker technologies and their applications in aquaculture genetics. Aquaculture 238: 1-37.

Maryanto AE. 2012. Genetic Distribution of Parental Candidate of Udang Galah from Natural Populations in Indonesia. [Thesis]. Sekolah Ilmu dan Teknologi Hayati, Institut Teknologi Bandung, Bandung. [Indonesian]

Neff BD, Gross MR. 2001. Microsatellite evolution in vertebrates: inference from ac dinucleotide repeats. Evolution 55: 1717-1733.

New MB. 2010. History and global status of freshwater prawn farming. In: New MB, Valenti WC, Tidwell JH, D'Abramo LR, Kutty MN (eds) Freshwater Prawns Biology and Farming. Wiley-Blackwell, United Kingdom. 
Peakall R, Smouse P. 2009. GenAlEx Tutorials-Part 1: Introduction to population genetic analysis. Australian National University, Canberra Australia. http://biology-assets.anu.edu.au/GenAlEx/Welcome.html

Peakall R, Smouse P. 2012. GenAlEx 6.5: genetic analysis in Excel Population genetic software for teaching and research-an update. Bioinformatics 28 (19): 2537-2539.

Schuelke, M. 2002. An economic method for the fluorescent labeling of PCR fragments: a poor man's approach to genotyping for research and high-throughput diagnostics. Nature Biotechnol 18: 233-234.

Shimizu M, Kosaka N, Shimada T, Nagahata T, Iwasaki H, Nagai H, Shiba T, Emi M. 2002. Universal fluorescent labeling (UFL) method for automated microsatellite analysis. DNA Res 9: 173-178.

Shinde DY, Lai FZ, Arnheim N. 2003. Taq DNA polymerase slippage mutation rates measured by PCR and quasi-likelihood analysis:
(CA/GT)n and (A/T)n microsatellites. Nucleic Acids Res. 31: 974980 .

Sonesson AK, Woolliams JA, Meuwissen THE. 2005. Kinship, relationship and inbreeding. In: Gjedrem $\mathrm{T}$ (eds) Selection and Breeding Programs in Aquaculture. Springer, Netherlands.

Walsh PS, Nicola J, Fildes NJ, Reynolds R. 1996. Sequence analysis and characterization of stutter products at the tetranucleotide repeat locus vWA. Nucleic Acids Res 24: 2807-2812.

Wowor D, Ng PKL. 2007. The giant freshwater prawns of the Macrobrachium rosenbergii species group (Crustacea: Decapoda: Caridea: Palaemonidae). Raffles Bul Zool 55: 321-336.

Yeh FC, Yang R, Boyle T. 1999. Quick User Guide: POPGENE Version 1.32 Microsoft window-based freeware for population genetic analysis. https://sites.ualberta.ca/ fyeh/popgene.html 